\title{
A Living Fish of Mesozoic Type
}

\section{By Dr. J. L. B. Smith, Rhodes University College, Grahamstown}

$E^{X}$ Africa semper aliquid novi. It is my privilege to announce the discovery of a Crossopterygian fish of a type believed to have become extinct by the close of the Mesozoic period. This fish was taken by trawl-net at a depth of about 40 fathoms some miles west of East London on December 22, 1938. It was alive when caught, and shortly after it died it was handed over to Miss Courtenay- mounted specimen, a responsible citizen-angler of East London stated that about five years ago he had found precisely such a fish, only considerably larger (sic), partially decomposed, cast up by the waves on a lonely part of the shore east of East London. When he returned with assistance, the monster had vanished with a risen tide. With regard to the present specimen, fortunately both

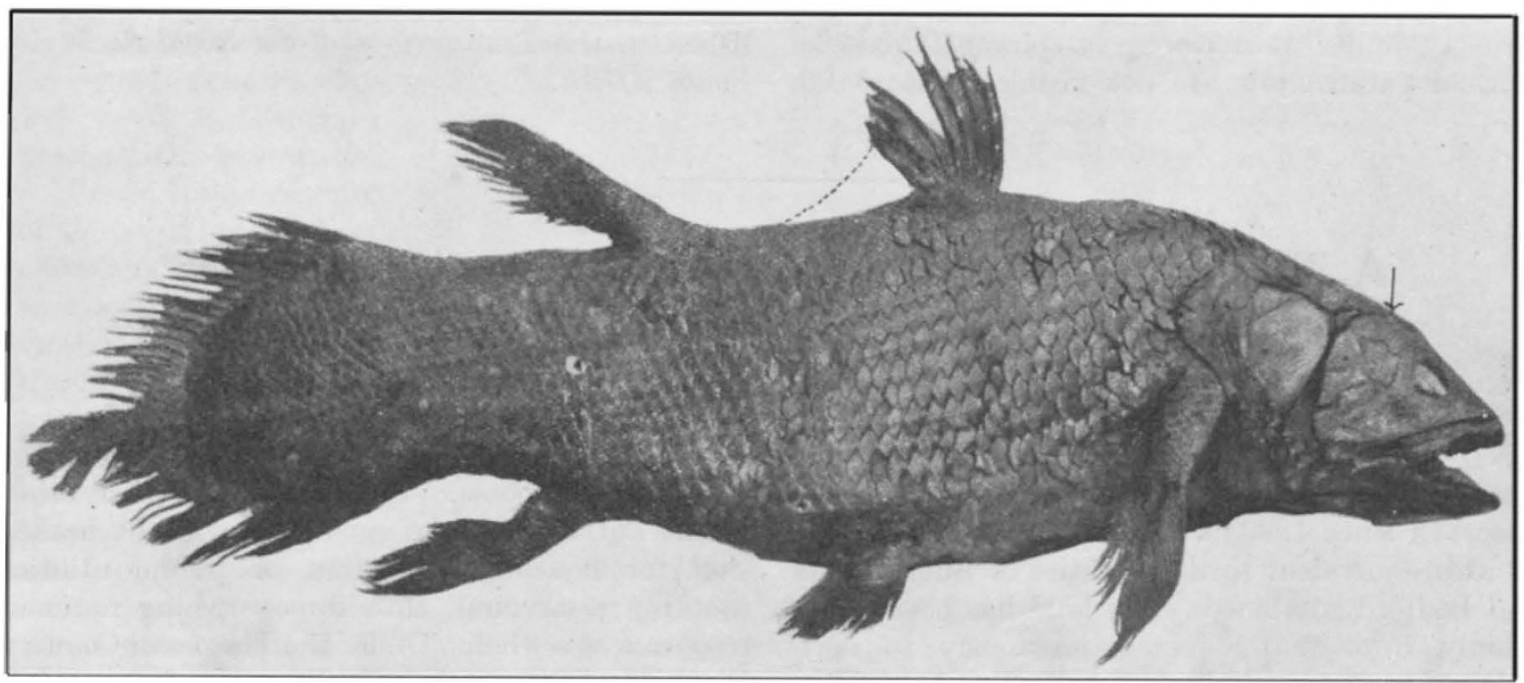

Comlacanthid Fish from East London, South Africa.

The small arrow shows the position of the spiracle, and the dotted line indicates the position of a membrane behind the first dorsal fin.

Latimer, curator of the East London Museum. Miss Latimer wrote to me, enclosing a sketch and brief particulars of the specimen. Owing to the seasonal disorganization of the postal services, the letter did not reach me at Knysna, some four hundred miles away, until ten days later. It was obvious from the sketch and notes that the fish was of a type believed long extinct. Immediate telephonic communication with the East London Museum revealed that, owing to lack of preserving equipment at that Institution, the putrefied body had been disposed of beyond any hope of redemption, and the fish had been mounted by the local taxidermist.

Since the fish was unquestionably alive when caught, there is at least a possibility that this zoological tragedy may be ameliorated by the capture of another specimen. This is not so remote as might appear. After careful inspection of the
Miss Latimer and the taxidermist were drawn to observe details of the carcass very closely, so that exhaustive independent questioning has left me with at least some definite information about the missing parts. Fortunately also, the terminal caudal portion of the vertebral column and part of the pectoral girdle remain. The skull is of course intact.

The specimen is $1,500 \mathrm{~mm}$. in total length, and weighed $127 \mathrm{lb}$. when caught. The colour was a bright metallic blue, which has faded to brown with preservation.

In major characters this remarkable specimen shows close relationship with the Mesozoic genus Macropoma Agassiz, of the family Cœlacanthidæ, order Actinistia. The gephyrocercal tail with protruding axial supplement, the normal first dorsal, the obtuse lobation of the remaining fins, the ganoin tubercle ornamentation on the scales and on some of the dermal bones of the head, the 
nature and arrangement of the dentigerous bones of the mouth, and the form of the dermal armour of the head, are all typically colacanthid.

The skeleton was cartilaginous, the vertebral column apparently tubular, and the whole fish extraordinarily oily. The fish has small spiracles situated as shown in the accompanying illustration, and a definite though not very obvious lateral line, which continues uninterrupted to the end of the supplementary caudal. Other differences from the known coelacanthid fishes are the pronounced pedunculation of the lobate pectorals, the reduction of the dermal armour of the head, and the presence of two small heavily ornamented bones at the anterior lower corner of the opercular plate, which probably correspond with the more fully developed inter- and sub-opercula of teleosts, also a similar posterior post-spiracular ossicle. Dermal parafrontals are not visible. There is a free tongue composed of four fused segments covered with presumably ossified tubercles.

It is probable that systematists will wish to propose a new family (some even a new order) for this fish, but $I$ am at present satisfied that it is close enough to the Mesozoic Colacanthidæ to justify its inclusion in that family. It has been noted that certain coelacanthid fishes underwent little apparent change from the Devonian to the Cretaceous. It is therefore not surprising that this species, which presumably has survived from the Mesozoic, should still retain most of the features which characterize that family.

For the fish described and figured above I propose the name Latimeria Chalumnoe gen. et sp. nov.; the full account of the species and of its taxonomic relationships will be published in the Transactions of the Royal Society of South Africa.

\section{A Tentative Land Fertility Map of England and Wales* \\ By Dr. L. Dudley Stamp, \\ Director of the Land Utilisation Survey of Britain}

JDUSTRIAL and housing development in 1 England and Wales is estimated to have absorbed since 1900 no fewer than 800,000 acresan area equivalent to the counties of Buckingham and Bedford combined. This land has been taken mainly from that devoted previously to agriculture and, once covered with bricks and mortar, it is lost to agricultural production for ever. Not only is the area concerned 2 per cent of the total area of the country, but it is also largely the best quality land. The modern factory with its horizontal layout requires level or gently undulating land, preferably well-drained; such land is also that most easily and cheaply developed as building estates and is also of the type required for aerodromes. It is precisely the best ploughland which has these characteristics and which is therefore being absorbed with alarming rapidity. Amongst the assets of the nation, its good agricultural land is surely one of the most precious, and yet, at the present time, enjoys little or no protection.

First-class arable land, suitable for intensive use as market gardens, occupies a strictly limited area in Britain-probably not more than 5 per cent-yet the value of even this land for agricultural purposes is below its 'development' value

* Summarized, by permission, from a report prepared at the request of the Royal Commission on the Geographical Distribution of tho Industrial Population and included in a public lect
the London School of Economies on January 31 . if it is so situated as to be suitable for housing or industrial purposes. Similarly, local and other public authorities take such land without hesitation for housing, recreation or public utilities (notably reservoirs), thus impoverishing national resources as a whole. Under the Town and Country Planning Acts, most agricultural land is 'zoned' for housing independently of its value for food production. Indeed, many town and regional plans completely ignore agricultural values and, as in the case of the South Essex regional plan, would result in the best land being devoted to housing and industry before the poorer land is touched. It is becoming increasingly apparent that, in the matter of land planning, local and national needs are in direct conflict, and that a National Planning Board is an urgent necessity.

If the national stability depends in any way on the maintenance and perhaps increase in home food production, and if the national health can be related in any way to a supply of fresh milk, vegetables and fruit, then the appropriate land must be preserved. The determination of the areas of best land thus becomes a problem of greatest urgency.

Several different bases might clearly be adopted in attempting a classification of the land of Britain. It might be made on the basis of a detailed soil survey, but this has not yet been made and there remain technical difficulties, including both finance 